\title{
Generation of THz Oscillations by Diodes with Resonant Tunneling Boundaries
}

\author{
O.V. Botsula*, V.O. Zozulia \\ V.N. Karazin Kharkiv National University, 4, Svoboda Sq., 61077 Kharkiv, Ukraine
}

(Received 23 June 2020; revised manuscript received 17 December 2020; published online 25 December 2020)

\begin{abstract}
Diodes with a resonant tunneling border are studied as possible sources of $\mathrm{THz}$ range. The diodes represent planar two-terminal structures containing a conductive channel and an active lateral border. The lateral border is an $\mathrm{AlGaAs} / \mathrm{GaAs}$-based double barrier resonant tunneling structure sandwiched between the channel and metal electrode. It electrically connects to an ohmic contact forming the anode. The operating principle of diodes is based on the use of transfer electron effect in the channel and electron transport throw the lateral border that can result in an increase in the oscillation frequency and extension of operating frequency range. The analysis was performed using ensemble Monte Carlo technique. Oscillation efficiency and frequency properties of the diode are determined. The relation between the maximum efficiency at a specific frequency and the magnitude of the applied bias is shown. It is found that the maximum efficiencies for lower operating frequencies correspond to large bias voltages, while ones at high frequencies are obtained for low bias voltages. Thus, it is possible to create a voltage-controlled oscillation source. The influence of a position of RTB and impurity doping on the generation efficiency of the diode has been investigated. The position of the active lateral border closer to the cathode contact results in a decrease in the generation efficiency and the rise in the oscillation frequency is demonstrated. The possibility to obtain generation in the range from 50 to $550 \mathrm{GHz}$ is shown. The maximum oscillation efficiency is close to $10 \%$ and corresponds to $110 \mathrm{GHz}$.
\end{abstract}

Keywords: Resonant tunneling border, Negative differential resistance, Doping level, Frequency range, Oscillation efficiency.

DOI: 10.21272/jnep.12(6).06037

PACS numbers: 85.30.Fg, 73.40.Kp, 73.40. - c

\section{INTRODUCTION}

The terahertz region of the electromagnetic spectrum has many important advantages such as the absence of the ionizing effect, high information capacity and ability to penetrate through opaque objects, possibility of highly directed radiation and others. This leads to the development of terahertz technology and devices $[1,2]$.

The unique spectral position of $\mathrm{THz}$ frequencies defines the development difficulties of compact solid-state sources of $\mathrm{THz}$ radiation. In most cases, a shift of the operating frequencies of existing devices into the $\mathrm{THz}$ range takes place $[3,4]$. Transferred electron devices and impact avalanche transit time diodes are welldeveloped high-frequency sources but are not widefrequency devices. Resonant tunneling diodes are highfrequency devices but they have a quite low output level. High electron mobility transistors (HEMTs) and heterojunction bipolar transistors (HBTs) often require low operating temperatures. Thus, creation of compact solid-state $\mathrm{THz}$ sources is of current interest.

Diodes with active lateral borders (LBD) can be considered as possible sources of $\mathrm{THz}$ range. LBDs can have both planar and sandwich structures [5]. The planar variant of an LBD is more suitable for practical realization and similar to several types of field effect transistor (FET) [6-8]. It consists of a conductive layer (active layer) formed on a high-resistivity (semiinsulating) substrate with two ohmic contacts. An active lateral border (ALB) is a semiconductor structure sandwiched between the metal electrode and the channel. Its electrical properties differ from those of the channel. The left and right edges of the ALB must not be aligned with the channel's ohmic contacts. The met- al electrode of the ALB electrically connects to one of the ohmic contacts by a metal jumper, thus, forming the anode of the diode. The other ohmic contact acts as the cathode.

Operating principles of the LBD have been considered in [5]. The main idea is a common use of the transfer electron effect in the channel of the diode and electronic processes in the LBD that can lead to the existence of negative difference resistance (NDR) and higher generation frequencies than do transfer electron devices (TED).

The necessary condition of the diode operation and the major difference of LBD from FET is the absence of modulation conductivity of the channel. The second condition arises from the NDR in the LBD. According to this reason, some types of ALB have been considered: tunneling, resonant tunneling, and $n$-boundaries $[5,9]$. An increase or decrease in the anode voltage with respect to the cathode causes changes in the current according to the electrical characteristics of both the channel and LBD.

Estimations of frequency properties and generation efficiency of LBDs with tunneling and resonant tunneling borders have been made in [5] by the use of simple models. Operating frequencies can be up to one terahertz as shown. However, electronic processes in considered diodes are very complicated. First of all, it is related to short channel effects, finite energy and momentum relaxation times.

The aim of the work is to study frequency properties and generation efficiency of GaAs-based LBDs with resonant tunneling boundary by using the Monte Carlo (MC) simulation and to determine perspectives of using the LBD in $\mathrm{THz}$ range.

*oleg.botsula@karazin.ua 


\section{THE DIODE STRUCTURE AND SIMULATION MODEL}

The lateral bounder is represented as a doublebarrier resonant tunneling structure (RTS). The RTS consists of two thin layers of a wide-gap semiconductor (AlGaAs) with a narrow-gap semiconductor (GaAs) in between. The regions on the outside of the barrier region contain non-doping layers (spacers) and highly doped contact regions. A cross-section of the LBD is shown in Fig. 1. The main part of the diode includes the semi-insulating (SI) substrate, $n$-channel and highly doped $\left(n^{+}\right)$contact regions.

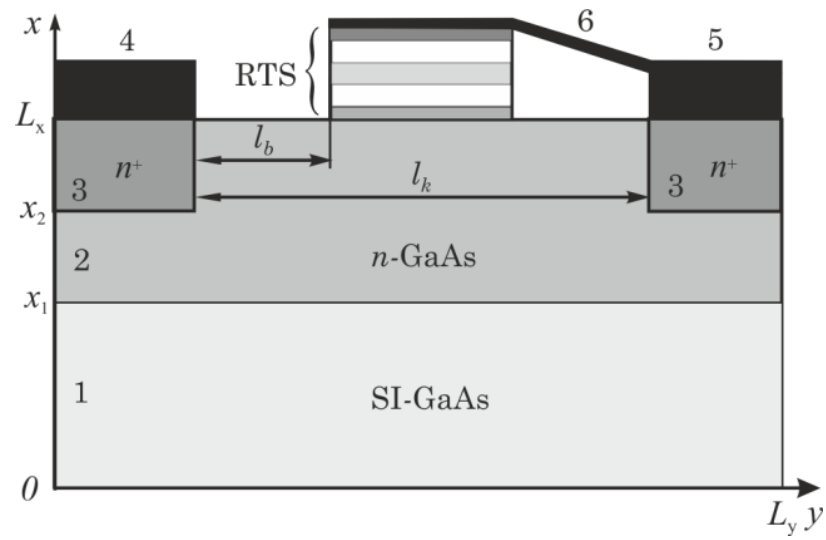

Fig. 1 - The diode structure: channel (1), semi-insulating substrate (2), highly doped contact region $\left(n^{+}\right)(3)$, cathode (4) and anode (5) metal contacts, metal jumper (6)

The domain's sizes are $L_{y}=1.28 \mu \mathrm{m}, L_{x}=0.32 \mu \mathrm{m}$. The channel's layer has a thickness of $0.16 \mu \mathrm{m}$ and a length of $0.98 \mu \mathrm{m}$. The donor concentrations were equal to (1-6) $\cdot 10^{22} \mathrm{~m}^{-3}$ and $10^{24} \mathrm{~m}^{-3}$ in the channel and contact regions, respectively.

The barrier and undoped spacer widths were taken around $2.5 \mathrm{~nm}$. The quantum well width was $5 \mathrm{~nm}$. The barriers height is $0.4 \mathrm{eV}$.

$2 \mathrm{D}$ modeling of the diode has been performed using a model described in [9]. It is based on Ensemble Monte Carlo (EMC) simulations and multigrid techniques of solving the Poisson equation. Three nonparabolic valleys $\Gamma, L$, and $X$ were used for the conduction band modeling of GaAs and AlGaAs. All scattering parameters, calculated peculiarities and parameters of materials to be used in modeling were taken into account similar to $[10,11]$.

\section{HIGH FREQUENCY GENERATION IN LBD}

Originally, it was suggested that the LBD would have a regime of negative differential mobility (NDC) [5]. NDC occurs over several regions of applied bias. The number of NDC regions is determined by the structure of the $\mathrm{LBD}$, its sizes and position relative to the cathode and anode contacts.

The results of MC simulation showed a great influence of the ballistic effect on the diode's characteristics. So, only one region of NDC was observed [9]. That is evidently connected with the electron transfer effect. It confirmed a strong influence of doping concentration on the value of NDC. The doping concentration was small, so the negative mobility was small too. But, an influence of LBD is very complicated. In particular, it can form the electron energy distribution in the channel and influence the steady state of the electron gas. LBD size of $160 \mathrm{~nm}$ was considered. The NDC appears for the ALB position more than $200 \mathrm{~nm}$ from cathode.

The use of the LBD as an active element for obtaining high frequency generation has been considered. It is suggested that the LBD is situated in resonators. The influence of the resonator is taken into account by setting the corresponding waveform voltage applied to the diode:

$$
U(t)=U_{0}+U_{1} \sin \omega t
$$

where $w$ is the resonant frequency, $U_{0}$ and $U_{1}$ are the bias voltage and first harmonic amplitude of an alternative voltage, respectively. The oscillation efficiency for the fundamental harmonic $(\eta)$ is determined as a function of the bias voltage and resonator frequency as in [9]. To determine $\eta$ the optimization has been carried out. The magnitude of $\eta$ was chosen to be maximal among all those obtained for different values of $U_{0}$ and $U_{1}$. The three values of doping concentration have been considered.

Fig. 2 shows the dependence of optimized generation efficiency on frequency for diodes with different donor impurity concentration in the channel of LBD.

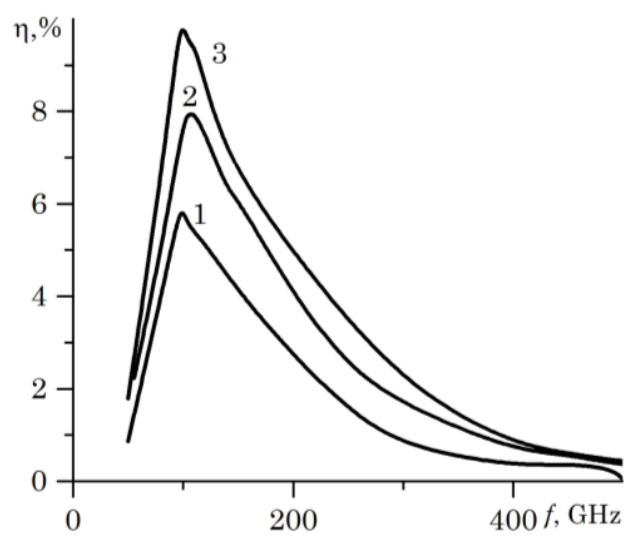

Fig. 2 - The optimized generation efficiency for diodes with different donor impurity concentration in the diode channel: $1-N_{d 3}=2 \cdot 10^{22} \mathrm{~m}^{-3}, 2-N_{d 3}=4 \cdot 10^{22} \mathrm{~m}^{-3}, 3-N_{d 3}=6 \cdot 10^{22} \mathrm{~m}^{-3}$

As can be seen from Fig. 2, the diode demonstrates generation in a wide frequency range above from 50 to more than $500 \mathrm{GHz}$. For all doping levels of the active region, the maximum oscillation efficiency corresponds to a frequency of about $100 \mathrm{GHz}$ which is weakly dependent on doping. The maximum $h$ is up to nearly $10 \%$ at doping level of $6 \cdot 10^{22} \mathrm{~m}^{-3}$. A decrease in the doping concentration leads to both a decrease in $h$ and narrowing of the operating frequency range. So, the cutoff frequency is from 400 to $550 \mathrm{GHz}$ for doping concentration in the channel of 2-6 $10^{22} \mathrm{~m}^{-3}$.

A resonant frequency corresponding to the maximum oscillation efficiency is in accordance with the value of inverse transit time. This confirmed that the electron transfer effect is the main reason of generation. On the other hand, the ordinary TED is known to operate in a narrow frequency band. Operating band of 
the LBD is significantly wider and extended toward the higher frequencies of above $0.5 \mathrm{THz}$.

The second feature of the LBD is a strong dependence of $h$ on the bias voltage. Fig. 3 shows frequency dependences of $\eta$ for several values of bias voltages and magnitude of the bias voltage $U_{0}$ corresponding to the maximum efficiency.

First of all, it should be noted that there is a relation between the maximum efficiency at a specific frequency and the magnitude of the applied bias.

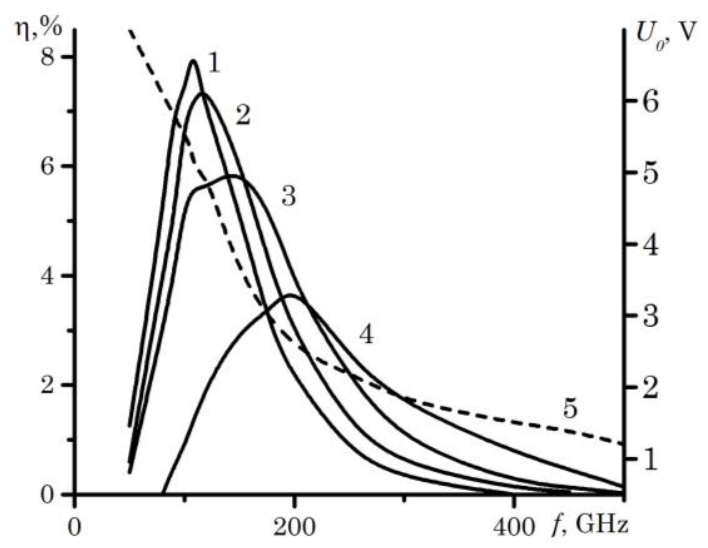

Fig. 3 - Dependence of the efficiency of the diode's generation (1-4) and bias voltage corresponding to the maximum gain (5) on frequency, $N_{d}=4 \cdot 10^{22} \mathrm{~m}^{3}: 1-5 \mathrm{~V}, 2-4 \mathrm{~V}, 3-3 \mathrm{~V}, 4-2 \mathrm{~V}$

Maximum efficiencies for lower operating frequencies correspond to large bias voltages, while those at high frequencies are obtained for low bias voltages (curve 5, Fig. 3). Thus, it is possible to create a voltagecontrolled oscillation source. Such diode characteristics are due to the features of NDR formation. Simulation showed that the moving strong field domain or an accumulation layer could not form. An electric field distribution in the diode localizes sufficiency in space. Electric field magnitude and field domain size change in time. Thus, this regime is similar to limited spacecharge accumulation mode. Electric field maximum is according to the position of the ALB on the channel. But itself ALB has little effect on diode NDR. Besides, the operating frequency range of the diode depends on the bias too, as seen from Fig. 3 .

The generation by the LBD also strongly depends on the ALB position on the top of the channel. The ALB position closer to the cathode contact results in a decrease in the generation efficiency. That fact is opposite to previous estimates obtained without account of short channel effects [5]. It was demonstrated that positive resistance of a part of the channel between the cathode and ALB is the reason of that. The ALB influences the electron energy distribution in the channel of the diode by both heating the electron gas and choosing the electron energy by RTS. The frequency corresponding to the maximum generation shifts towards small values $(110 \mathrm{GHz})$.

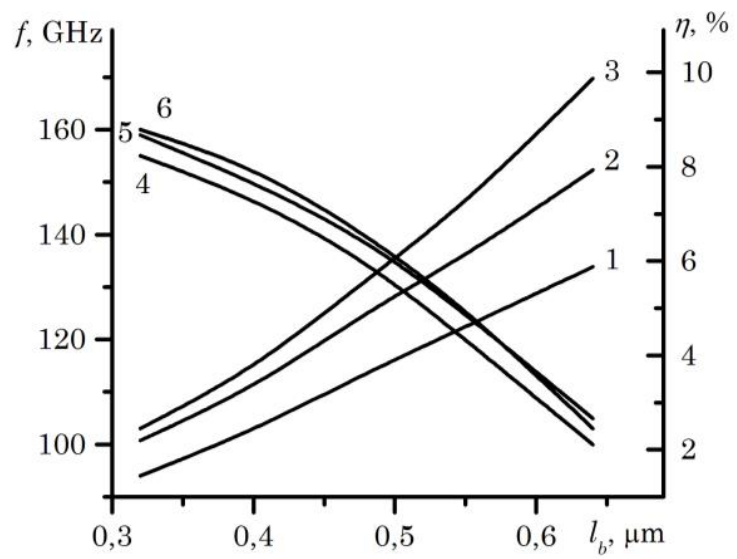

Fig. 4 - Dependence of the maximum efficiency (1-3) and the frequency corresponding to the maximum gain (4-6) on the LBT position

It is worth noting that the frequency corresponding to the maximum oscillation efficiency in space between the cathode and the ALB of $0.64 \mu \mathrm{m}$ still equals about $110 \mathrm{GHz}$ at all doping concentrations in the channel. Furthermore, ranges of the frequency change do not exceed $20 \mathrm{GHz}$ for all distances between the cathode and the ALB.

\section{CONCLUSIONS}

The potentiality of GaAs based planar diodes with active lateral resonant tunneling boundaries for the generation of $\mathrm{THz}$ signals has been analyzed. $\mathrm{MC}$ simulations have been used to confirm the operating principles of diodes and the dependence of their performance on several geometrical and physical parameters. The LBDs with a channel length of around $1 \mu \mathrm{m}$ exhibit oscillations at frequencies higher than $500 \mathrm{GHz}$. The maximum oscillation efficiency was up to $10 \%$ and has been obtained at a frequency of around $110 \mathrm{GHz}$ that corresponds to the time of electron transfer across the diode channel.

The obtained result supports the argument that ALB increases oscillation frequency of a planar diode. This effect was also observed in other LBDs, for example, in the ALB with $n$-boundaries [12].

A wide operating frequency range is provided by strong dependence of the generation frequency on the bias and ALB position. In fact, the considered device is a broadband source in the sub- $\mathrm{THz}$ range.

\section{REFERENCES}

1. M. Hangyo, Jpn. J. Appl Phys. 54, No12, 120101 (2015).

2. D.M. Mittleman, J. Appl. Phys. 122, 230901 (2017).

3. H. Song, T. Nagatsuma, Handbook of terahertz technologies: devices and applications (Singapore: Pan Stanford Publishing: 2015).

4. K. Ahi, Opt. Eng. 56 No 9, 090901 (2017).
5. E.D. Prokhorov, O.V. Botsula, O.A. Reutina, 23rd International Crimean Conference - Microwave and Telecommunication Technology (CRIMICO-2013), art. No 13882554, 139, (Sevastopol: IEEE: 2013).

6. F. Capasso, S. Sen, A.Y. Cho, Appl. Phys. Lett. 51 No 10, 526 (1987). 
7. T.K. Woodward, T.C. Mc Gill, H.F. Chung, R.D. Burnham, Appl. Phys. Lett. 51 No 19, 1542 (1987).

8. G. Zhou, Y. Lu, R. Li, Q. Zhang, W. Hwang, Q. Liu, T. Vasen, C. Chen, H. Zhu, J. Kuo, S. Koswatta, T. Kosel, M. Wistey, P. Fay, A. Seabaugh, H. Xing, IEEE Elect. Dev. Lett. 32 No 11, 1516 (2011)

9. O. V. Botsula, K. H. Pryhodko, V. O. Zozulia, 9th International Conference on Ultrawideband and Ultrashort Impulse Signals (UWBUSIS-2018), art. No 18230006, 256 (Odessa:
IEEE: 2018).

10. I. Vurgaftman, J.R. Meyer, L.R. Ram-Mohan, J. Appl. Phys. 89 No 11, 5815 (2001)

11. K. Brennan,N. Mansour, J. Appl. Phys. 69 No 11, 7844 (1991).

12. O. V. Botsula, K. H. Pryhodko, V. O. Zozulia, 2nd Ukraine Conference on Electrical and Computer Engineering (UKRCON-2019), art. No 19093801, 752 (Lviv: IEEE: 2019).

\title{
Генерація терагерцових коливань діодами з резонансно-тунельними границями
}

\author{
О.В. Боцула, В.О. Зозуля
}

Харківський національний університет імені В.Н. Каразіна, пл. Свободи, 4, 61077 Харків, Украӥна

Діоди з резонансно-тунельною границею розглядаються як можливі джерела терагерцового діапазону. Діоди $е$ планарними структурами з двома контактами, що містять провідний канал і активну бі чну границю. Бічна границя являе собою двохбар'ерну резонансно-тунельну структуру на основі $\mathrm{AlGaAs} / \mathrm{GaAs}$, яка розміщуються між каналом і металевим електродом та електрично з'єднана з омічним контактом аноду. Принцип роботи діодів полягае у поеднанні ефекту міждолинного переносу в каналі та електронного транспорту через бічну границю, що призводить до збільшення частоти коливань та розширення частотного діапазону роботи. Аналіз проводився з використанням багаточастинкового методу Монте-Карло. Визначено ефективність коливань та частотні властивості діода. Показано існування співвідношення між максимальною ефективністю на конкретній частоті та величиною зміщення, що подаеться на діод. Встановлено, що максимальні значення ефективності генерації при роботі на низьких частотах відповідають великим напругам зміщення, тоді як на високих частотах низьким. Таким чином, існуе можливість створення керованого напругою джерела коливань. Досліджено вплив положення резонансно-тунельної границі та величини легування на ефективність генерації діода. Положення активної границі ближче до катодного контакту призводить до зниження ефективності генерації та підвищення частоти. Показано можливість отримання генерації в діапазоні від 50 до 550 ГГц. Максимальна ефективність генерації склала 10 \%, що відповідае частоті 110 ГГц.

Ключові слова: Резонансно-тунельна границя, Негативна диференціальна провідність, Рівень легування, Частотний діапазон, Ефективність генерації. 